\title{
The Service of the Romanian Orthodox Church to Migrants
}

\begin{abstract}
Through the concrete steps taken by its members (clergy, believers, and monks), from 1998 until now, the Romanian Orthodox Church has carried out extensive actions to monitor and solve the migration crisis.

Thanks to this approach, initiated and improved by its current Primate, His Beatitude, Patriarch Daniel, both in the country and in the diaspora of our Church, the phenomenon of migration was not only be monitored, but also solved both in accordance with Church rules and with State laws, as well as those of the Law of the European Union, that is, of the EU Member States.

From our article, the informed reader will be also able to see that, in its actions for monitoring and solving the migration problem, our Church has taken into account both the guidelines issued by the bodies of the Ecumenical Council of Churches and the guiding principles stated by the leaders of the two Churches, Catholic and Orthodox, namely, His Holiness, Pope Francis, and His Beatitude, the Ecumenical Patriarch, Bartholomew I, in their joint Declarations on the issue of migration, hence the ecumenical nature of the approach to the issue of migration.
\end{abstract}

Keywords: the migration crisis, the phenomenon of migration, hospitality, the diaspora

\section{Prolegomena}

The term 'stranger' ( $\xi \dot{\varepsilon} v o \varsigma$ ), also denoting migrant or immigrant, was used by Holy Apostle Paul in both his Epistles to the Romans (12:13) and to the Hebrews (13:2), and the adjective 'lover or receiver of strangers' ( $\varphi \uparrow \lambda \circ \xi \varepsilon v i ́ \alpha)$ can be found in two Pauline epistles (I Tim. 3:2; Titus 1:8) and in the First Epistle of Holy Apostle Peter (I Peter 4:9). It should be 
noted that both Holy Apostles, Peter and Paul, asked Christians - in categorical terms - to "offer hospitality to one another without grumbling" (I Peter 4: 9; Rom. 12-13).

In the beginning, Christians were also "foreigners" among the Gentiles, just as the Jews were "scattered among the Greeks" (John 7:35), or among the other foreign nations (Babylonians, Egyptians etc.). In fact, the members of the early Christian communities came both from the "twelve tribes" who were at the time "scattered" (James 1:1) and from the heathen nations, so that the first Christians, descended from the latter, indeed, lived - in the words of the Holy Apostle Peter - "among strangers" (I Peter 1:1).

The New Testament testimonies thus justify our statement that the phenomenon of migration was not only known, but also experienced even by the first Christians, whose duties - expressly provided by the Holy Apostles and their successors, in grace and apostolic faith ${ }^{1}$ - were not only a "rule" to obey, but also a kind of "vade-mecum" for their daily lives, ${ }^{2}$ hence, therefore, the obligation of every Christian to cultivate the virtue of hospitality, and especially of "philoxenia" (love for strangers), which, for almost two millennia, has become a kind of "alter ego" for all who claim to be disciples of Christ, that is, Christians.

For Christians, philoxenia ( $\left.\varphi \imath \lambda_{0} \xi \varepsilon v i ́ \alpha\right)$, meaning 'the love for strangers,' which for two millennia has materialized in receiving, hosting, and feasting with any "stranger" at their doorstep or visits their homeland, is indeed a divine commandment (cf. Gen. 18; Lev. 19, 33-34; Matt. 25:35; Rom. 12-13; Heb. 13: 2), since, according to the teaching of the Holy Scriptures, in every one of us, including the one who is a stranger to our nation and our law, that is, to our religious faith, we must see Christ the Lord Himself (Matt. 25:35; 25:38; 25, 43-44).

The same biblical teaching tells us that receiving and hosting a "stranger" - whether to our nation or our religion - is a 'service' ( $\lambda \varepsilon \imath \tau$ covía) (Luke 1:23; Philippians 2:17), which is also expressed through an act of hospitality (cf. Rom. 15:26; III John 5).

In the spirit of the same biblical Christian teaching, we Christians today are also "strangers", for we are but "temporary inhabitants" on this earth (Eph. 2:19), like the early Christians, who lived among the twelve

${ }^{1}$ L. STAN: "Succesiunea apostolic" [Apostolic succession]. Studii Teologice 5-6 (1955), pp. 305-323.

${ }^{2}$ N. V. DuRă: “Îndatorirea credincioşilor privind viața creştină în lumina Sfintelor canoane" [The duty of the faithful regarding the Christian life in the light of the Holy canons]. Altarul Banatului 10-12 (1993), pp. 18-26; N. V. Dură: "Sfânta Scriptură şi creştinii din primele veacuri" [Holy Scriptures and the Christians of the first ages]. Indrumător bisericesc 7 (1986), pp. 5-16. 
tribes of the chosen people and among the heathen nations, whence the duty of every Christian - regardless of their ethnic origin or religious creed - is to manifest a permanent availability, and, ipso facto, hospitality to any stranger (cf. Job 31:17; 1 Tim. 5:10). In fact, for receiving, hosting, and material and spiritual help to a fellow human being - whether a stranger or not - we receive a reward from God (cf. Matt. 10:42; Mark 9:41).

However, the fact which must not be ignored or kept hidden is that even some pagans have cultivated this kind of hospitality towards foreigners. In this respect, the Romans were a telling example. Indeed, in the 2nd century $\mathrm{AD}$, the famous jurisconsult Ulpianus forbade "injuring" one alterum (another), that is, your fellow man, and imposed the obligation of the subjects of the Roman Empire to give "everyone what they deserve" (suum quique tribuere) (Justiniani Institutiones, lb. I, 3).

Among these subjects of the Roman Empire (individuals, citizens, or simply human beings or persons) were also those aliens ab nostra familia (strangers to our family), ${ }^{3}$ as Cicero dubbed them.

To some peoples of Europe - including the Romanian people, who were baptized by Saint Andrew the Apostle ${ }^{4}$ - migration has been and still is perceived and experienced primarily as an "alienation" or "removal from one's people and one's property," country and nation, as well as from the law or faith of their fathers, as confirm to us the "manuscript of the first translation" of the Leastvita or Scara Raiului (Leastvita or the Ladder of Heaven) written by Saint John Climacus (ca. 579-649), which was translated from Slavonic into Romanian by a monk, Varlaam from the Secu Monastery (the future metropolitan of Moldavia (1632-1653) between the years 1610 and 1613.

Nowadays, this "distance" or alienation from their "property," that is, from their homeland, is also known as migration, which as a crisis is faced not only by the states of the world, but also by the Christian denominations, hence the volens nolens involvement of their leaders through the Ecumenical Council of Churches and the Churches' Commis-

${ }^{3}$ G. Guțu: Dicționar latin-român [Latin-Romanian Dictionary]. Bucureşti 1983, p. 65.

${ }^{4}$ N. V. Dură: „Scythia Mynor” (Dobrogea) şi Biserica ei apostolică. Scaunul arhiepiscopal şi mitropolitan al Tomisului (sec. IV-XIV) [Scythia Mynor" (Dobrudja) and its Apostolic Church. The archbishopric and metropolitan see of Tomis (IV-XIV centuries)]. Bucureşti 2006, pp. 58-60.

${ }^{5}$ Leastvița sau Scara Raiului de Ioan Scărarul [Leastvita or the Ladder of Heaven by Saint John Climacus]. Trans. E. Munteanu. Ed. O. Panaite. Iaşi 2007, p. 77.

6 † Daniel, Mitropolitul Moldovei şı Bucovinei: Cuvânt Inainte, in Leastvița sau Scara Raiului [Foreword, in Leastvița or the Ladder of Heaven], p. 6. 
sion for Migrants in Europe, as well as (ecclesiastical and state) national bodies and institutions, as is the case with Romania.

\section{The Romanian Orthodox Church and the phenomenon of migration}

According to its statutes, "The Romanian Orthodox Church is the community of Orthodox Christians, clergy, monks and laymen, canonically constituted in parishes and monasteries in the dioceses of the Romanian Patriarchate located inside and outside Romania [...]" (Art. 1 of The Statutes for the organisation and functioning of the Romanian Orthodox Church from 2020; hereinafter: The Statutes).

Therefore, the Romanian diaspora is an integral part of the Romanian Orthodox Church, hence its constant concern and mission for the clergy and its believers, ${ }^{7}$ including "migrants" and their families, regardless of their legal status (working, studying, mixed marriages etc.). ${ }^{8}$

However, in order to better understand the way in which the Romanian Orthodox Church is involved in the process of solving the migration problem - which is also faced by remaining Churches in the European Union, ${ }^{9}$ regardless of their religious creed, - it is obviously necessary to know the official position of this Church, and, ipso facto, the attitude of its members (clergy, believers and monks) ${ }^{10}$ towards migration, as well as

7 Regarding the Romanian diaspora, see N. V. DuRă: “Comunitățile ortodoxe române de peste hotare, o preocupare permanentă a Bisericii Ortodoxe Române" [The Romanian Orthodox communities abroad, a permanent concern of the Romanian Orthodox Church]. Studii Teologice 1 (1986), pp. 8-23; N. V. Dură: "Statele Uniunii Europene şi cultele religioase" [The European Union States and the religious cults]. Ortodoxia 2 (2009), pp. 49-72.

${ }^{8}$ N. V. DurĂ, P. Kroczek, C. Mititelu: Marriage from the Roman Catholic and Orthodox points of view. Krakow 2017, pp. 66-70; N. V. Dură: "Căsătoriile mixte în lumina învățăturii şi a practicii canonice ortodoxe" [Mixed marriages in the light of Orthodox canonical teaching and practice]. Ortodoxia 1 (1988), pp. 92-113.

${ }^{9}$ Regarding the contribution of the Churches to the construction of the EU, see N. V. Dură: "Bisericile creştine şi aportul lor la construcția Europei” [Christian churches and their contribution to the construction of Europe]. Ars aequi. Revistă de studii şi cercetări sociale şi juridice 4 (2006), pp. 177-183.

${ }^{10}$ Regarding the members of a local, autocephalous Orthodox Church, as is the case of the Romanian Orthodox Church, see N. V. DurĂ; Le Régime de la synodalité selon la législation canonique, conciliaire, oecuménique, du I Ir millénaire. Bucureşti 1999, pp. 89-286, 916—983; N. V. DuRă: "Monahii, al treilea element constitutiv al Bisericii" 
the concrete actions it took both within its administrative-territorial units, that is, in the "dioceses" (archbishops and bishops) grouped in metropolises, within the "Romanian Patriarchate" (Art. 6 para. 2 of The Statutes), and "outside the borders of Romania" (Art. 6 para. 2 of The Statutes), that is, from its diaspora, which "includes [...] the Romanian Orthodox Christians abroad (Art. 5 para. 1). ${ }^{11}$

Thus, both the position of this Orthodox Church organized in accordance with an ethnic and geographical framework, ${ }^{12}$ well specified and expressed by "the 29 dioceses in the country" and by the 14 dioceses "outside the borders of Romania," 13 as well as through the declarations of the hierarchs of these dioceses, and, most of all, of the Primate of this Church - which are precisely the subject of the present study will prove to us sufficiently the fact that the service for the disadvantaged, excluded or vulnerable persons ${ }^{14}$ - as, for example, in the case of migrants - is an indisputable reality.

[Monks, the third constituent element of the Church]. Biserica Ortodoxă Română 7-12 (2003), pp. 469-483; N. V. DuRĂ: “The 'Scythian Monks' (Daco-Roman) and their Contribution to the European Christian Humanist Culture." In: Dialogue of Civilizations. Ed. D. Muskhelishvili. New York 2010, pp. 33-42.

11 "Statutul pentru organizarea şi funcționarea Bisericii Ortodoxe Române" [The Status for the Organization and Functioning of the Romanian Orthodox Church]. Monitorul Oficial al României, I, 97 (10.02.2020), p. 12. Regarding this Statute and its ecclesiological and canonical-legal principles, see C. Mititelu: "The Status of Organization and Functioning of the Romanian Orthodox Church. Ecclesiological and canonical-juridical considerations." In: The current Statutes for the organisation and functioning of the Romanian Orthodox Church. Tradition and Innovation. Ed. C. RuşEȚ. Cluj-Napoca 2016, pp. $144-166$.

12 On the affirmation of these (ethnic and geographical) ecclesial-canonical principles in the life of the Church of the first millennium, see N. V. Dură: Le Régime de la synodalité..., pp. 383-530; N. V. DuRă: "Legislația canonică a Sinodului II ecumenic şi importanța sa pentru organizarea şi disciplina Bisericii" [The canonical legislation of the Second Ecumenical Council and its importance for the organization and discipline of the Church]. Glasul Bisericii 6-8 (1981), pp. 630-671; N. V. Dură: "Biserica creştină în primele patru secole. Organizarea şi bazele ei canonice" [The Christian Church in the first four centuries. Its organization and canonical bases]. Ortodoxia 3 (1982), pp. 451-469; N. V. Dură: "The Protos in the Romanian Orthodox Church According to its Modern Legislation.” Kanon 9 (1989):, pp. 139-161.

${ }^{13}$ Interviu inedit: Patriarhul Daniel vorbeşte despre misiunea Bisericii în ultimii 10 ani [Extraordinary interview: Patriarch Daniel talks about the mission of the Church in the last 10 years], https://basilica.ro/interviu-inedit-patriarhul-daniel-vorbeste-despremisiunea-bisericii-in-ultimii-10-ani/ [access: 13.07.2020].

${ }^{14}$ C. Mititelu: "The Human Rights and the Social Protection of Vulnerable Individuals." Journal of Danubius Studies and Research 1 (2012), pp. 70_77. 


\section{The Sunday of the Romanian Migrants}

On August 22-23, 2005 in the Archdiocese of Iasi — led at the time by Metropolitan Daniel, the current Patriarch of the Romanian Orthodox Church, - took place the first Presbyterial Conference on the phenomenon of migration from parishes: opportunities, problems and pastoral perspectives attended by about 900 priests. ${ }^{15}$

This Presbyterial Conference - with a topic of pressing actuality had the aim to make the clergy and the faithful of our Church aware of the phenomenon of migration, which "manifested itself - it was stated in the final document of this Conference - since ancient times," 16 that is, more precisely - as we have stated in the Prolegomena of our study since the Apostolic age.

In the same final Document of the Conference it was emphasized that, after the removal of the former totalitarian regime, that is, after December 1989, in Romania, "the phenomenon of migration (permanent or temporary) escalated," 17 caused primarily by the search for a workplace. ${ }^{18}$

The following "methods of pastoral care of the Church" ${ }^{19}$ were also proposed at this Conference, namely: a) The Church must cooperate with the competent institutions of the state in the field of migration; b) the priests must inform and explain to those who wish to emigrate the risks involved in such a decision; c) an intensification of the collaboration with the Romanian Orthodox dioceses in the diaspora is recommended; d) The State and the Church must contribute to the prevention and solution of the problems generated by migration.

As shown above, it was recommended that the Mother Church intensify its collaboration with its own diaspora, namely, with the Romanian Orthodox dioceses outside the country's borders, in order to find a common denominator in addressing and solving the migration problem.

At the same Conference, from August 22 to 23, 2005, His Eminence Metropolitan Daniel proposed that the Sunday after the feast of the Dormition of the Mother of God (August 15) be dedicated to Romanian migrants. Metropolitan Daniel's proposal, which since then would become a constant reality in the life of the Romanian Orthodox Church,

15 The final document of the Presbyterial Conference dedicated to the phenomenon of migration, https://basilica.ro/documentul-final-al-conferintei-preotesti-consacratafenomenului-migratiei/ [access: 22.08.2020].

16 The final document of the Presbyterial Conference.

17 Ibidem.

18 Ibidem.

${ }^{19}$ Ibidem. 
was reactivated on the occasion of August 20, 2006, when the first Sunday of Romanian migrants was celebrated.

On that occasion, Metropolitan Daniel also offered the first "special prayers for Romanians abroad" 20 at the end of the Divine Liturgy.

During the Divine Liturgy on the Sunday of the Romanian Migrants prayers of request, thanksgiving and asking for help are offered not only for the Romanian emigrants, but also for the emigrants of the world.

\section{Ecumenical bodies that the Romanian Orthodox Church collaborates with on refugees and migrants}

The former Metropolitan of Moldova and Bucovina His Eminence Daniel also played a decisive role in the establishment of the first "forum" for the refugees from the Romanian Orthodox Church. This first ecumenical body on migration, which was established in our Church in 1998 as the Ecumenical Forum for Refugees and Migrants (ARCA), was not only the first of the organizations of this kind in Romania, but also one of the ecclesiastical institutions that were effectively involved in the process of monitoring and social-humanistic assistance of migrants.

An ecumenical body that the Romanian Orthodox Church collaborates with on migrants is, of course, the Ecumenical Council of Churches, which through the Churches' Commission for Migrants in Europe, within the Conference of European Churches, works with our Church on monitoring the phenomenon of migration and solving the crisis produced by it.

In the ecclesiastical environment (both Catholic and Orthodox) it is also well known that migrants are entitled to express their religious faith according to the rights covered by jus divinum and jus naturale ${ }^{21}$ that is, to exercise their right to religious freedom, ${ }^{22}$ which

${ }^{20} 20$ august 2006 - "Duminica migranților" [The Sunday of the "Romanian Migrants'], https://basilica.ro/20-august-2006-duminica-migrantilor/. [access: 26.08.2020].

${ }^{21}$ N.V. Dură: "Loi morale, naturelle, source du Droit naturel et de la Morale chrétienne." In: La morale au crible des religions. Ed. M.Th. Unvoy. Paris 2013, pp. 213-233; N. V. DuRĂ: "The Right and its Nature in the Perception of the Roman Jurisprudence and of the Great Religions of the Antiquity." In: Rethinking Social Action. Core Values. Ed. A. SANDU et al. Bologna 2015, pp. 517-524.

${ }^{22}$ N. V. DuRă; “Drepturile şi libertățile omului în gândirea juridică europeană. De la 'Justiniani Institutiones' la 'Tratatul instituind o Constituție pentru Europa”” [Human 
was and remains in fact the matrix of fundamental human rights and freedoms. ${ }^{23}$

Through their social and humanitarian activities, Churches can indeed contribute to the assurance and protection of fundamental human rights, ${ }^{24}$ and by their involvement in the observance of these rights and freedoms, including the "dignity of all human beings," 25 Churches must become "active partners" and "social actors" in any society.

As stated in the study of the Churches' Commission for Migrants in Europe, from 2008, it must be borne in mind that migrants should not lose their religious identity ${ }^{26}$ because "a loss of religious identity may

rights and freedoms in European legal thinking. From 'Justiniani Institutiones' to the 'Treaty establishing a Constitution for Europe']. Analele Universității Ovidius. Series: Drept şi Ştiințe Administrative 1 (2006), pp. 129-151; N.V. Dură: "Les droits fondamentaux de l'homme et leur protection juridique." Analele Universității Dunărea de Jos Galați, Fascicula XXII, Drept şi Administrație public 2 (2008), pp. 19-23; N.V. Dură: “Despre libertatea religioasă și regimul ei juridic. Consideraţii şi evaluări" [On religious freedom and its legal regime. Considerations and evaluations]. Jurnalul juridic național: teorie şi practică 2 (36) (2019), pp. 25-31.

${ }^{23}$ N.V. Dură: “The Fundamental Rights and Liberties of Man in the EU Law." Dionysiana 1 (2010), pp. 431-464; N. V. DuRă: "Principii şi norme generale ale Dreptului Uniunii Europene privind protecția juridică a drepturilor omului" [General principles and rules of European Union law on the legal protection of human rights]. In: RO-RUSNIPPONICA. Craiova 2010, pp. 32-36; N.V. DuRĂ: "Dreptul la libertatea de Religie, 'fons' şi 'fundamentum' al celorlalte libertăți ale omului” [The right to freedom of religion, 'fons' and 'fundamentum' of other human freedoms]. Legea şi viața 12 (2014), pp. 7-12; N.V. Dură, C. Mititelu, "Human rights and their universality. From the rights of the 'individual' and of the 'citizen' to 'human' rights". In: Exploration, Education and Progress in the third Millennium Proceedings, I, 4. Galați 2012, pp. 103-127.

${ }^{24}$ N. V. Dură: "Drepturile şi libertățile fundamentale ale omului şi protecția lor juridică. Dreptul la religie şi libertatea religioasă" [Fundamental human rights and freedoms and their legal protection. The right to religion and religious freedom]. Ortodoxia 3-4 (2005), pp. 7-55; N. V. DuRĂ: "Principalele organisme şi organizații internaționale cu preocupări şi atribuții în domeniul promovării şi asigurării protecției juridice a drepturilor omului" [The main international bodies and organizations with concerns and responsibilities in the field of promoting and ensuring the legal protection of human rights]. Dionysiana 1 (2007), pp. 18-25; N. V. DuRĂ: "General Principles of European Union Legislation Regarding the Juridical Protection of the Human Rights." Journal of Danubius Studies and Research 2 (2013), pp. 7-14.

25 D. Jackson, A. Passarelli: Mapping Migration Mapping Churches' Responses Europe Study (2008), 28, https://ccme.eu/wp-content/uploads/2018/12/2008-05-28_ CCME_Publ_-_Mapping_migration_-_Mapping_Churches_responses.pdf [access: 23.08.2020].

${ }^{26}$ N.V. Dură: “The Right to Religion: Some Consideration of the Principal International and European Juridical Instruments." In: Religion and Equality. Law in conflict. Eds. W. C. Durham Jr., D. Thayer. UK: Routledge, 2016, pp. 15-24; N. V. Dură: "The Right to the 'Freedom of Conscience', Legal Basis for the Educational and Missionary Activity of Religious Denominations." Ecumeny and Law 5 (2017), pp 147-170; 
eventually lead to a loss of ethical values, with the consequence that these migrants will be even more disoriented and rootless in the host society $[\ldots] . . " 27$

The same European Commission of the World Council of Churches has called on religious communities to also become "a bridging tool for integration, avoiding marginalization, and overcoming the frustrations felt by migrant faith communities which may lead to radicalization of the religious community or individuals within it." 28

However, the loss of the religious identity of migrants can inexorably lead to the loss of their religious - Christian values, and, ipso facto, of the "cultural-humanist heritage of Europe," 29 created over the centuries by the clergy and believers of the two parts of the former Roman Empire, that is, both the Pars Orientis and the Pars Occidentis.

In fact, it is known that not only the "Christian Republic" was built on the foundation of this Empire, but also the Christian Europe, ${ }^{30}$ where the right to dignitas humana, "supreme value" for any "rule of law, democratic and social" (Art. 1, para. 3 of the Romanian Constitution) of ours days, has been and is synonymous with the observance and assurance of the legal protection of any person, regardless of race, nationality, ethnic origin, and religion. ${ }^{32}$

N. V. Dură: "About the Freedom of Religion and the Laicity. Some Considerations on the Juridical and Philosophical Doctrine." Bulletin of the Georgian National Academy of Sciences 4 (2019), pp. 156-164.

27 D. Jackson, A. Passarelli: Mapping Migration..., p. 27.

${ }^{28}$ Ibidem.

29 N.V. DuRă: “Valorile religios-creştine şi 'moştenirea culturală, religioasă şi umanistă a Europei'. 'Laicitate' şi 'libertate religioasă"” [Religious-Christian values and "Europe's cultural, religious and humanist heritage". "Secularism" and "religious freedom"]. In: Modernitate, postmodernitate şi religie. Iaşi 2005, pp. 19-35.

${ }^{30}$ N.V. Dură: “Bisericile Europei şi „Uniunea Europeană”. Ecumenism, reconciliere creştină şi unitate europeană" [The Churches of Europe and the "European Union”. Ecumenism, Christian reconciliation and European unity]. In: Biserica în misiune. Patriarhia română la ceas aniversar. Bucureşti 2005, pp. 771—794.

31 N.V. Dură: "Dreptul la demnitate umană (dignitas humana) şi la libertate religioasă. De la 'Jus naturale' la 'Jus cogens"' [The right to human dignity (dignitas humana) and religious freedom. From 'Jus naturale' to 'Jus cogens']. Analele Universității Ovidius. Seria: Drept şi Ştiințe Administrative 1 (2006), pp. 86-128.

${ }^{32}$ N.V. Dură: "The right to freedom of religion." Annales Canonici 10 (2014), pp. 27-40; N. V. DurĂ, C. Mititelu: "The Freedom of Religion and the Right to Religious Freedom." In: Conference on Political Sciences, Law, Finance, Economics \& Tourism, I. Sofia 2014, pp. 831-838; N.V. DuRĂ, C. Mititelu: "The right to Freedom of Religion in the Jurisprudence of the European Court." Journal of Danubius Studies and Research 1 (2014), pp. 141-152. 


\section{Migration as another determining factor of the urgent need for collaboration between the State and the Church in the social-humanitarian field}

Through the activity of its members, clergy, believers, and monks, ${ }^{33}$ the Romanian Orthodox Church has proven to be not only a source of stability and overcoming the marginalization of migrants, refugees, stateless people etc. in Romanian society, but also a real and effective help for them to be able to self-express and live their religious faith truly and effectively, and, ipso facto, to exercise their right to religious freedom, which in Romania $^{34}$ is expressly provided for in both the country's Constitution ${ }^{35}$ and in the Law of Religious Denominations. ${ }^{36}$

Like the other Churches or Christian denominations in the EU member states, ${ }^{37}$ the Romanian Orthodox Church has proven to be a decisive factor in the process of integration of migrants, thus contributing not only to the elimination of any form of marginalization or religious radicalization of them, be it as individuals or groups, but also to the prohibi-

${ }^{33}$ N. V. DurĂ: "Christianism in Pontic Dacia. The 'Scythian Monks' (Daco-Roman) and their Contribution to the Advance of Ecumenical Unity and the Development of the European Christian Humanist Culture." Revue Roumaine d'Histoire 1-4 (2003), pp. $5-18$.

${ }^{34}$ N. V. Dură: "Religious Freedom in Romania.” Theologia Pontica 3-4 (2012), pp. $9-24$.

${ }_{35}$ N. V. DuRă: "Despre drepturile și libertățile omului prevăzute în textul constituțional român. Considerații şi evaluări” [On the human rights and freedoms provided in the Romanian constitutional text. Considerations and evaluations]. Revista Națională de Drept 10-12 (2019), pp. 53-63.

${ }_{36}$ N. V. Dură: "Legea nr. 489/2006 privind libertatea religioasă şi regimul general al Cultelor religioase din România" [Law no. 489/2006 on religious freedom and the general regime of religious cults in Romania]. In: Biserica Ortodoxă şi Drepturile omului: Paradigme, fundamente, implicații. Bucureşti 2010, pp. 290-311.

37 Regarding these Churches in the EU, see N. V. Dură: “'Privilegii' şi 'discriminări' în politica religioasă a unor State ale Uniunii Europene' ['Privileges' and 'discrimination' in the religious policy of some European Union States], Biserica Ortodoxă Română 1-3 (2006): 491-510; N. V. Dura: "Relațiile Stat-Culte religioase în U.E. 'Privilegii' şi 'discriminări' în politica 'religioasă' a unor State membre ale Uniunii Europene" [StateReligious Cults Relations in the EU. 'Privileges' and 'discriminations' in the 'religious' policy of some Member States of the European Union]. Analele Universității Ovidius. Series: Drept şi Ştiințe Administrative 1 (2007), pp. 20-34; N. V. DuRĂ: "Proselytism and the Right to Change Religion: The Romanian Debate." In: Law and Religion in the 21st Century. Relations between States and Religious Communities. Ed. S. Ferrari, R. Cristofori. England: Ashgate Publishing Limited, 2010, pp. 279-290; N. V. DuRĂ: "Prozelitismul şi dreptul de-a schimba religia în lumina legislației române" [Proselytism and the right to change religion in the light of Romanian legislation]. Ortodoxia 2 (2010), pp. 11-21. 
tion of any form of discrimination based on religion ${ }^{38}$ and, ipso facto, the exercise of the rights of migrant parents to provide their children with a religious education according to their own religion, Christian denominations or religious beliefs. ${ }^{39}$

It should be noted that the Romanian state authorities have officially recognized, whenever necessary, "the important role of the Romanian Orthodox Church and other Churches and denominations recognized in the national history of Romania and in the life of Romanian society" (Art. 7, para. 2 of Law no. 489/2006 on religious freedom and the general regime of cults). ${ }^{40}$

On October 2, 2007, the Government of Romania and the Romanian Patriarchate signed a Protocol of collaboration in the field of social inclusion ${ }^{41}$ which was in fact "the natural and practical consequence of the new Law on Religious Denominations that recognizes the contribution of the Romanian Orthodox Church and other religious denominations in the life of the Romanian society, the denominations (religious cults) being appreciated as factors of social peace and social partners of the Romanian State."42

Law 489/2006 on religious freedom and the legal regime of denominations ${ }^{43}$ indeed expressly emphasizes the role of the Romanian Orthodox Church in the life of Romanian society, and especially in the social field (cf. Art. 7 para. 2).

It should also be mentioned that this Protocol of collaboration in the field of social inclusion - between the Romanian Government and the Romanian Patriarchate - has to be regarded as an evidence that, in Romania, the two institutions, namely, the State and the Church, genuinely took into consideration both the laws of European Union concerning the

${ }^{38}$ N. V. Dură: "Rules of national and international law prohibiting all forms of discrimination based on religion or religious belief." Annales Canonici 12 (2016), pp. $45-64$.

${ }^{3}$ N. V. Dură: "Provisions of International Law on the Parents' Right to Provide their Children with a Religious Education." In: The fundamentals of our spirituality. Batumi 2018, pp. 240-248.

${ }^{40}$ Text republished in the Official Gazette of Romania, Part I no. 201 of March 21, 2014.

${ }^{41}$ C. Mititelu: “The Cooperation Protocol on Social Inclusion, Concluded between the Government of Romania and the Romanian Patriarchate. Juridical and Canonical Considerations." Teologia 2(59) (2014), pp. 58-70.

${ }^{42} \dagger$ Daniel, Patriarch of Romania, Speech delivered after the signing of the Protocol of cooperation in the field of social inclusion between the Government of Romania and the Romanian Patriarchate http://patriarhia.ro/images/pdf/SocialFilantropic/PROTOCOL_incluziune.pdf [access: 16.07.2020].

${ }^{43}$ See N. V. DurĂ: “The Law no. 489/2006 on Religious Freedom and General Regime of Religious Cults in Romania.” Dionysiana 1 (2008), pp. 37-54. 
migrants, and its Social Charter, ${ }^{44}$ and, ipso facto, the international legal regime on human rights. ${ }^{45}$

Nowadays, the Christian Churches are also volens-nolens in a "process" of globalization, ${ }^{46}$ whose effect - not always beneficial to the Christian world, including the assertion of religious freedom - is also visible in the traditional Churches. For example, it would be enough to mention that the former relations between the State and the Church, such as those of a "collaboration" nature for the public good - common to the Byzantine era (6th-15th centuries) ${ }^{47}$ - are increasingly rare, hence not only the obstacles which Christians encounter in their activity of preaching the gospel of Christ to all peoples (cf. Matt. 28:19), but sometimes also the possibility of the two basic institutions of human society, the State and the Church, to cooperate concretely and effectively in the social field, including the social protection of vulnerable persons, as is the case for stateless persons, migrants, and refugees.

Although Romania is not particularly attractive as a labour market, one can still see that asylum seekers fleeing to our country, even if only as a transit state towards more economically developed countries (Germany, the UK, France, Italy, Spain etc.), hence the fact that only few of them ask the Romanian authorities for help with their settlement in Romania.

The refugee community, which actually represents the main migrant group in Romania, remains one of the applicants receiving this aid, so that our country has also become one of the "applicant countries", ${ }^{48}$

${ }^{44}$ C. Mititelu, M. Mitra Radu: "The European Social Charter (Revised) and the Protection of the Human Rights." “Ovidius" University Annals, Economic Sciences Series Volume 1(13) (2013), pp. 1593-1598.

${ }^{45}$ N. V. Dură: "The Rights of the Persons who lost their Autonomy and their Social Protection." Journal of Danubius Studies and Research 1 (2012), pp. 86-95; C. Mititelu: "The Children's Rights. Regulations and Rules of International Law." Ecumeny and Law 3 (2015), pp. 151-169.

${ }^{46}$ C. Mititelu: "The "Globalization Era" and the Right of the Church to Preach the Gospel to All Peoples. Canonical-Juridical Considerations and Assessments." Ecumeny and Law 5 (2017), pp. 127-146.

47 C. Mititelu, A. Tinu: "Provisions of State and Church law on the cooperation between the State and the Church in the first millennium." In: The fundamentals of our spirituality. Batumi 2018, pp. 358-368; N. V. Dură, C. Mititelu: "The State and the Church in IV-VI Centuries. The Roman Emperor and the Christian Religion." In: Conference on Political Sciences, Law, Finance, Economics \& Tourism, I. Sofia 2014, pp. 923-930; N. V. Dură: "The Relationships between the State and the Church and their Legal Regime. Rules of International and National Law." Bulletin of the Georgian National Academy of Sciences 4 (2018), pp. 192-201.

${ }^{48}$ Migration Trends in Selected Applicant Countries. Vol. IV. Romania, More Out' than In' at the Crossroads between Europe and the Balkans. Ed. S. LĂZĂRoIU. Vienna 2003, p. 20. 
hence the existence of a National Office for Refugees, which is "responsible with managing asylum application and the situation of refugees in Romania." ${ }^{49}$ At the same time, this Office "is responsible for collecting relevant statistics on refugees and asylum seekers and managing special centres for refugees in collaboration with local authorities." 50

Regarding EU law on the integration of refugees, it should be noted that, in accordance with its provisions, "persons with refugee status are entitled to social benefits, shelter and could be part of dedicated cultural and educational programmes. In addition, refugees have free access to labour market and the law guarantees their equal treatment. Access to training programmes to improve skills and adapt to local market is specified in the law as well." ${ }^{51}$

In their collaboration activity in the social-humanitarian field, both the Romanian State and the Orthodox Church, of course, must take into account the provisions stated by the EU legislation. Actually, this reality is also an indication that the two basic institutions, the State and the Church, are obligated to take part in concrete activities in this field.

\section{In lieu of conclusions}

From the review - although a brief one - of both the perception and approach to the migration phenomenon by the Romanian Orthodox Church, and of its concrete actions for solving the migration crisis, the reader of this study will be able to easily ascertain and remember that, since 1998, the first body on migration was established in the Romanian Orthodox Church.

It will also be clear that the issue of migration has been the subject of public debate in the life of this Church since the beginning of this millennium. This explains the fact that, in 2006, His Eminence Daniel Metropolitan of Moldova and Bucovina - currently Patriarch of Romania - instituted for the first time, in the Romanian area, the Sunday of the Romanian Migrants, which in 2019 would become - also due to the initiative of His Beatitude - a day of honour in the entire Romanian Orthodox Church dedicated to Romanian migrants.

\footnotetext{
${ }^{49}$ Migration Trends in Selected Applicant Countries..., p. 60.

${ }^{50}$ Ibidem, p. 60.

${ }^{51}$ Ibidem.
} 
The fact that the issue of migration has become a constant concern for the members of our Church, that is, clergy, laymen and monks, is emphasized by the actions taken by the hierarchs of the Holy Synod, who, through the authorized voice of its Primate, the Romanian Orthodox Church expressed its attitude and its effective and real involvement in solving the problem of migration both nationally and internationally.

Hence the obvious finding that the Romanian Orthodox Church has been and still is - along with the other Orthodox Churches, with which it has always coordinated its social and humanitarian policies on migrants - also a partner of interreligious ecumenical dialogue, through which the migration crisis was addressed and joint action has also been taken.From the pages of this study, however, it can be seen that the Romanian Orthodox Church has coordinated its actions, in collaboration, with the State in order to monitor and solve the migration crisis.

Certainly, we cannot ignore the fact that the meritorious activity of the Romanian Orthodox Church - regarding the approach and solution of the migration problem - is also emphasized by its contribution in the area of its own diaspora, in which Romanian migrants (leaving the country in search of a better paid job, or for studies etc.), received from it not only religious assistance or religious education, transferred mainly through Sunday Schools, but also through the assistance offered - with the help of the brethren of the other Christian Cults, and especially of the Roman Catholic Church - by the servants of the Romanian Orthodox Church, from the diaspora, for the insertion of refugees and migrants in the society of the host country.

Thus, through all these concrete actions both of the clergy and of its believers in the country and in the diaspora - including the official statements of its hierarchs - the Romanian Orthodox Church did nothing but translate into life the word of the Holy Scriptures (Matt. 5:35) and to express its will to be an active factor in the common effort of the Christian world to solve the problem of migration.

The pages of our study also reveal the fact that migration is not only a theological subject, but also one with a pronounced interdisciplinary character, that is, sociological, politological, legal, etc. Indeed, for us Christians, the theme of migration has first of all a deeply theological sublayer (cf. Fac. 18; Lev. 19, 33-34 etc.). Hence the virtue of hospitality, which has been cultivated and is still clearly affirmed by some Christian nations in our European area, - such as the Romanian and the Polish - and which is materialized by hospitality to any foreigner who demands shelter and food, regardless of race, religion or social status. 
It is also not surprising that, in the pages of our study, we referred first of all to jus divinum and then to jus naturale and jus scriptum, because, as far as migrants are concerned, their grounds are primarily found in the text of Holy Scriptures.

In the same context of our approach, in order to illustrate as truthfully as possible the way in which the Romanian Orthodox Church fulfills its "service" towards immigrants and migrants, we also referred to the state legislation, in order to emphasize that in their joint action, the State and the Church - the two basic institutions of the Romanian society - can make a real contribution to the materialization of this "ministry", whose exponent remains - at the national level — the Primate of our Church, Father Patriarch Daniel.

Indeed, through his concrete initiatives and measures that he took at the level of the whole Church - in the country and in the diaspora he proved to be a "diligent servant" (Philippians 2: 25) and a servant of migrants and immigrants, and thus appeared as a "servant" of all men (cf. Matt. 20:26; Mk 9:35), and, ipso facto, as a "servant of Christ" (I Cor. $4: 1$ ), for which "philoxenia" (love for strangers) is nothing but the love of Christ (cf. Matt. 25, 35), which was and is the basis of any form of hospitality for the Romanian faithful people.

This service of the Romanian Orthodox Church towards migrants has always been included both in the concerted actions of the Orthodox Church and in the approaches and orientations initiated and materialized by the ecumenical tutelary forums, namely the World Council of Churches, the Conference of European Churches and the Churches' Commission for Migrants in Europe.

Finally, we would like to point out that, in addressing the issue of migration and for solving this problem, the Romanian Orthodox Church had as its first reference and orientation the Joint Declarations ${ }^{52}$ of the two leaders of the Christian Churches, namely Catholic and Orthodox, and in this case, of the Joint Declarations on "Migration" adopted by His Holiness Pope Francis and the Ecumenical Patriarch Bartholomew, "Declarations" which, for Catholic and Orthodox Christians in our countries, are a true vade-mecum and an ecumenical landmark.

52 See Common Declaration of Pope Francis and the Ecumenical Patriarch Bartholomew I, 25 May 2014, http://www.vatican.va/content/francesco/en/speeches/2014/ may/documents/papa-francesco_20140525_terra-santa-dichiarazione-congiunta.html [access: 17.06.2020]. 


\section{Bibliography}

"Common Declaration of Pope Francis and the Ecumenical Patriarch Bartholomew I," 25 May 2014, http://www.vatican.va/content/francesco/en/ speeches/2014/may/documents/papa-francesco_20140525_terra-santa-dichiarazione-congiunta.html .[access: 17.06.2020].

$\dagger$ Daniel, Patriarch of Romania: "Speech delivered after the signing of the Protocol of cooperation in the field of social inclusion between the Government of Romania and the Romanian Patriarchate," http://patriarhia.ro/images/ pdf/SocialFilantropic/PROTOCOL_incluziune.pdf .[access: 16.07.2020].

"Duminica migranților," 20 August 2006 [The Sunday of the "Romanian Migrants'], https://basilica.ro/20-august-2006-duminica-migrantilor/ .[access: 26.08.2020].

DurĂ N. V.: "About the Freedom of Religion and the Laicity. Some Considerations on the Juridical and Philosophical Doctrine." Bulletin of the Georgian National Academy of Sciences 4 (2019), pp. 156-164.

DurĂ N. V.: “Bisericile creştine şi aportul lor la construcția Europei” [Christian churches and their contribution to the construction of Europe]. Ars aequi. Revistă de studii şi cercetări sociale şi juridice 4 (2006), pp. 177-183.

DurĂ N. V.: "Biserica creştină în primele patru secole. Organizarea şi bazele ei canonice" [The Christian Church in the first four centuries. Its organization and canonical bases]. Ortodoxia 3 (1982), pp. 451-469.

DurĂ N. V.: “Bisericile Europei şi „Uniunea Europeană”. Ecumenism, reconciliere creştină şi unitate europeană" [The Churches of Europe and the "European Union”. Ecumenism, Christian reconciliation and European unity]. In: Biserica în misiune. Patriarhia română la ceas aniversar, Bucureşti 2005, pp. 771-794.

Dură N. V.: "Căsătoriile mixte în lumina învățăturii şi a practicii canonice ortodoxe" [Mixed marriages in the light of Orthodox canonical teaching and practice]. Ortodoxia 1 (1988), pp. 92-113.

DurĂ N. V.: “Christianism in Pontic Dacia. The 'Scythian Monks' (DacoRoman) and their Contribution to the Advance of Ecumenical Unity and the Development of the European Christian Humanist Culture." Revue Roumaine d'Histoire 1-4 (2003), pp. 5-18.

Dură N. V.: “Comunitățile ortodoxe române de peste hotare, o preocupare permanentă a Bisericii Ortodoxe Române" [The Romanian Orthodox communities abroad, a permanent concern of the Romanian Orthodox Church]. Studii Teologice 1 (1986), pp. 8-23.

Dură N. V.: “Dreptul la libertatea de Religie, „fons” şi „fundamentum” al celorlalte libertăți ale omului" [The right to freedom of religion, "fons" and "fundamentum" of other human freedoms]. Legea şi viața 12 (2014), pp. 7-12.

DuRĂ N. V.: "Despre drepturile și libertățile omului prevăzute în textul constituțional român. Considerații şi evaluări" [On the human rights and freedoms provided in the Romanian constitutional text. Considerations and evaluations]. Revista Națională de Drept 10-12 (2019), pp. 53-63. 
Dură N. V.: “Despre libertatea religioasă și regimul ei juridic. Considerații şi evaluări" [On religious freedom and its legal regime. Considerations and evaluations]. Jurnalul juridic național: teorie şi practică 2 (36) (2019), pp. $25-31$.

Dură N. V.: “Dreptul la demnitate umană (dignitas humana) şi la libertate religioasă. De la 'Jus naturale' la 'Jus cogens"' [The right to human dignity (dignitas humana) and religious freedom. From "Jus naturale" to "Jus cogens”]. Analele Universității Ovidius. Seria: Drept şi Ştiințe Administrative 1 (2006), pp. 86-128.

Dură N. V.: “Drepturile şi libertăţile fundamentale ale omului şi protecția lor juridică. Dreptul la religie şi libertatea religioasă" [Fundamental human rights and freedoms and their legal protection. The right to religion and religious freedom]. Ortodoxia 3-4 (2005), pp. 7-55.

DuRĂ N. V.: “Drepturile şi libertățile omului în gândirea juridică europeană. De la 'Justiniani Institutiones' la 'Tratatul instituind o Constituţie pentru Europa" [Human rights and freedoms in European legal thinking. From "Justiniani Institutiones" to the "Treaty establishing a Constitution for Europe”]. Analele Universității Ovidius. Series: Drept şi Ştiințe Administrative 1 (2006), pp. 129-151.

Dură N. V.: “General Principles of European Union Legislation Regarding the Juridical Protection of the Human Rights." Journal of Danubius Studies and Research 2 (2013), pp. 7-14.

DURĂ N. V.: "Îndatorirea credincioşilor privind viața creştină în lumina Sfintelor canoane" [The duty of the faithful regarding the Christian life in the light of the Holy canons]. Altarul Banatului 10-12 (1993), pp. 18-26.

DuRĂ N. V.: “Legea nr. 489/2006 privind libertatea religioasă şi regimul general al Cultelor religioase din România” [Law no. 489/2006 on religious freedom and the general regime of religious cults in Romania]. In: Biserica Ortodoxă şi Drepturile omului: Paradigme, fundamente, implicații.” Bucureşti 2010, pp. $290-311$.

DuRĂ N. V.: “Legislația canonică a Sinodului II ecumenic şi importanța sa pentru organizarea şi disciplina Bisericii" [The canonical legislation of the Second Ecumenical Council and its importance for the organization and discipline of the Church]. Glasul Bisericii 6-8 (1981), pp. 630-671.

DurĂ N. V.: “Les droits fondamentaux de l'homme et leur protection juridique." Analele Universității Dunărea de Jos Galați, Fascicula XXII, Drept şi Administrație public 2 (2008), pp. 19-23.

Dură N. V.: "Loi morale, naturelle, source du Droit naturel et de la Morale chrétienne." In : La morale au crible des religions. Ed. M. Th. Unvoy. Paris 2013, pp. $213-233$.

Dură N. V.: Le Régime de la synodalité selon la législation canonique, conciliaire, oecuménique, du I'r millénaire. Bucureşti 1999.

DurĂ N. V.: "Monahii, al treilea element constitutiv al Bisericii" [Monks, the third constituent element of the Church]. Biserica Ortodoxă Română 7-12 (2003), pp. 469-483. 
DurĂ N. V.: "Proselytism and the Right to Change Religion: The Romanian Debate." In: Law and Religion in the 21st Century. Relations between States and Religious Communities. Eds. S. Ferrari, R. Cristofori. England: Ashgate Publishing Limited, 2010, pp. 279-290

DurĂ N. V.: “Provisions of International Law on the Parents' Right to Provide their Children with a Religious Education." In: The fundamentals of our spirituality, Batumi: 2018, pp. 240-248.

Dură N. V.: “Prozelitismul şi dreptul de-a schimba religia în lumina legislaţiei române" [Proselytism and the right to change religion in the light of Romanian legislation]. Ortodoxia 2 (2010), pp. 11-21.

DURĂ N. V.: "Rules of national and international law prohibiting all forms of discrimination based on religion or religious belief." Annales Canonici 12 (2016), pp. 45-64.

DurĂ N. V.: "The Fundamental Rights and Liberties of Man in the EU Law." Dionysiana 1 (2010), pp. 431-464.

DurĂ N. V.: "The Protos in the Romanian Orthodox Church According to its Modern Legislation." Kanon 9 (1989), pp. 139-161.

DuRĂ N. V.: "Valorile religios-creştine şi 'moştenirea culturală, religioasă şi umanistă a Europei'. 'Laicitate' şi 'libertate religioasă"' [Religious-Christian values and 'Europe's cultural, religious and humanist heritage'. 'Secularism' and 'religious freedom']. In: Modernitate, postmodernitate şi religie, Iaşi 2005, pp. $19-35$.

DuRĂ N. V.: “'Privilegii’ şi 'discriminări’ în politica religioasă a unor State ale Uniunii Europene" ['Privileges' and 'discrimination' in the religious policy of some European Union States]. Biserica Ortodoxă Română 1-3 (2006), pp. $491-510$.

DuRĂ N. V.: “Principalele organisme şi organizații internaționale cu preocupări şi atribuții în domeniul promovării şi asigurării protecției juridice a drepturilor omului" [The main international bodies and organizations with concerns and responsibilities in the field of promoting and ensuring the legal protection of human rights]. Dionysiana 1 (2007), pp. 18-25.

DUR Ă N. V.: “Principii şi norme generale ale Dreptului Uniunii Europene privind protecția juridică a drepturilor omului" [General principles and rules of European Union law on the legal protection of human rights]. In: RO-RUS-NIPPONICA. Craiova 2010, pp. 32-36

Dură N. V.: “Relațiile Stat-Culte religioase în U.E. 'Privilegii' şi 'discriminări' în politica 'religioasă' a unor State membre ale Uniunii Europene" [State-Religious Cults Relations in the EU. 'Privileges' and 'discriminations' in the 'religious' policy of some Member States of the European Union]. Analele Universității Ovidius. Series: Drept şi Ştiințe Administrative 1 (2007), pp. 20-34.

Dură N. V.: "Religious Freedom in Romania." Theologia Pontica 3-4 (2012), pp. $9-24$.

DuRĂ N. V.: “Sfânta Scriptură şi creştinii din primele veacuri” [Holy Scriptures and the Christians of the first ages]. Indrumător bisericesc 7 (1986), pp. 516. 
DurĂ N. V.: “Statele Uniunii Europene şi cultele religioase" [The European Union States and the religious cults]. Ortodoxia 2 (2009), pp. 49-72.

DurĂ N. V.: “'Scythia Mynor' (Dobrogea) şi Biserica ei apostolică. Scaunul arhiepiscopal şi mitropolitan al Tomisului (sec. IV-XIV) ['Scythia Mynor' (Dobrudja) and its Apostolic Church. The archbishopric and metropolitan see of Tomis (IV-XIV centuries)]. Bucureşti 2006.

DurĂ N. V.: “The 'Scythian Monks' (Daco-Roman) and their Contribution to the European Christian Humanist Culture." In: Dialogue of Civilizations. Ed. D. Muskhelishvili. New York 2010, pp. 33-42.

Dură N. V.: “The Law no. 489/2006 on Religious Freedom and General Regime of Religious Cults in Romania." Dionysiana 1 (2008), pp. 37-54.

DurĂ N. V.: "The Relationships between the State and the Church and their Legal Regime. Rules of International and National Law." Bulletin of the Georgian National Academy of Sciences 4 (2018), pp. 192-201.

DurĂ N. V.: “The Right and its Nature in the Perception of the Roman Jurisprudence and of the Great Religions of the Antiquity." In: Rethinking Social Action. Core Values. Ed. A. SANDu et al. Bologna 2015, pp. 517-524.

DurĂ N. V.: “The right to freedom of religion." Annales Canonici 10 (2014), pp. $27-40$.

DurĂ N. V.: "The Right to Religion: Some Consideration of the Principal International and European Juridical Instruments." In: Religion and Equality. Law in conflict. Ed. W. C. Durham Jr., D. Thayer. UK: Routledge, 2016, $15-24$.

DurĂ N. V.: “The Right to the 'Freedom of Conscience'. Legal Basis for the Educational and Missionary Activity of Religious Denominations." Ecumeny and Law 5 (2017), pp. 147-170.

DurĂ N. V.: “The Rights of the Persons who lost their Autonomy and their Social Protection." Journal of Danubius Studies and Research 1 (2012), pp. $86-95$.

DurĂ N. V., Mititelu C.: "Human rights and their universality. From the rights of the 'individual' and of the 'citizen' to 'human' rights." In: Exploration, Education and Progress in the third Millennium Proceedings I, 4. Galați 2012, pp. $103-127$.

DurĂ N. V., Mititelu C.: “The Freedom of Religion and the Right to Religious Freedom.” In: Conference on Political Sciences, Law, Finance, Economics \& Tourism, I. Sofia 2014, pp. 831-838.

DurĂ N. V., Mititelu C.: "The right to Freedom of Religion in the Jurisprudence of the European Court." Journal of Danubius Studies and Research 1 (2014), pp. $141-152$.

DurĂ N. V., Mititelu C.: “The State and the Church in IV-VI Centuries. The Roman Emperor and the Christian Religion." In: Conference on Political Sciences, Law, Finance, Economics \& Tourism, I, Sofia 2014, pp 923930.

Dură N. V., Kroczek P., Mititelu C.: Marriage from the Roman Catholic and Orthodox points of view. Krakow 2017. 
GuȚu G.: Dicționar latin-român [Latin-Romanian Dictionary]. Bucureşti 1983.

"Interviu inedit: Patriarhul Daniel vorbeşte despre misiunea Bisericii în ultimii 10 ani" [Extraordinary interview: Patriarch Daniel talks about the mission of the Church in the last 10 years], https://basilica.ro/interviu-ineditpatriarhul-daniel-vorbeste-despre-misiunea-bisericii-in-ultimii-10-ani/ .[access: 13.07.2020].

JaCKSON D., Passarelli A.: Mapping Migration Mapping Churches' Responses Europe Study (2008). https://ccme.eu/wp-content/uploads/2018/12/2008-05-28_ CCME_Publ_-_Mapping_migration_-_Mapping_Churches_responses.pdf [access: 23.08.2020].

Leastvița sau Scara Raiului de Ioan Scărarul [Leastvita or the Ladder of Heaven by Saint John Climacus]. Trans. E. Munteanu. Ed. O. Panaite. Iaşi 2007.

Migration Trends in Selected Applicant Countries. Vol. IV: Romania, More Out' than In' at the Crossroads between Europe and the Balkans. Ed. S. LĂZĂroIU. Vienna 2003.

Mititelu C.: "The 'Globalization Era' and the Right of the Church to Preach the Gospel to All Peoples. Canonical-Juridical Considerations and Assessments.” Ecumeny and Law 5 (2017), pp. 127-146.

Mititelu C.: “The Children's Rights. Regulations and Rules of International Law." Ecumeny and Law 3 (2015), pp. 151-169.

Mititelu C.: "The Cooperation Protocol on Social Inclusion, Concluded between the Government of Romania and the Romanian Patriarchate. Juridical and Canonical Considerations." Teologia 2 (59) (2014), pp. 58-70.

Mititelu C.: "The Human Rights and the Social Protection of Vulnerable Individuals." Journal of Danubius Studies and Research 1 (2012), pp. 70-77.

Mititelu C.: “The Status of Organization and Functioning of the Romanian Orthodox Church. Ecclesiological and canonical-juridical considerations." In: The current Statutes for the organisation and functioning of the Romanian Orthodox Church. Tradition and Innovation. Ed. C. RuşET,. Cluj-Napoca 2016, pp. $144-166$.

Mititelu C., Mitra Radu M.: “The European Social Charter (Revised) and the Protection of the Human Rights." "Ovidius" University Annals, Economic Sciences Series Volume XIII 1 (2013), pp. 1593-1598.

Mititelu C., Tinu A.: "Provisions of State and Church law on the cooperation between the State and the Church in the first millennium." In: The fundamentals of our spirituality. Batumi 2018, pp. 358-368.

Stan L.: "Succesiunea apostolic" [Apostolic succession]. Studii Teologice 5-6 (1955): 305-323.

"Statutul pentru organizarea şi funcționarea Bisericii Ortodoxe Române" [The Status for the Organization and Functioning of the Romanian Orthodox Church]. Monitorul Oficial al României I, 97 (10. 02. 2020), pp. 11-47.

The final document of the Presbyterial Conference dedicated to the phenomenon of migration, https://basilica.ro/documentul-final-al-conferintei-preotesti-consacrata-fenomenului-migratiei/ [access: 16.07.2020]. 


\title{
CăTĂLINA Mititelu
}

\section{Servizio della Chiesa Ortodossa Rumena verso i migranti}

\begin{abstract}
Dalle pagine di questo studio, il lettore avrà l'opportunità di apprendere che i migranti che si sono stabiliti in Romania dopo il 1998 sono stati curati dalla Chiesa ortodossa rumena; allo stesso tempo, la loro presenza tra i rumeni ha permesso alla Chiesa di sottolineare che era ed è ancora una „serva” dell'uomo, inclusi rifugiati, migranti, apolidi. Infatti, dal 1998 fino a oggi, la Chiesa ortodossa rumena compie grandi sforzi tramite i suoi membri (chierici, credenti, monachi) per monitorare e risolvere la crisi migratoria. Grazie a questo approccio, avviato e migliorato dall'attuale Primate, Sua Santità il Patriarca Daniele, sia nel Paese che nella diaspora, il problema delle migrazioni non solo poteva essere monitorato, ma anche risolto in conformità con i regolamenti ecclesiastici, nonché con il diritto statale e con il diritto dell'Unione Europea, ovvero con i regolamenti degli Stati membri dell'UE in cui la nostra Chiesa ha una parte della sua diaspora. Il lettore potrà notare che nelle sue attività di monitoraggio e di risoluzione del problema delle migrazioni, la nostra Chiesa ha tenuto conto sia degli orientamenti emanati dagli organi del Consiglio ecumenico delle Chiese, che dei principi guida formulati dai responsabili delle due Chiese. : cattolica e ortodossa, e cioè da Sua Santità Papa Francesco e da Sua Santità il Patriarca Ecumenico Bartolomeo I. Si tratta delle loro Dichiarazioni congiunte sulle migrazioni, che testimoniano della natura ecumenica del loro approccio alla suddetta questione.
\end{abstract}

Parole chiave: crisi migratoria, fenomeno migratorio, ospitalità, diaspora

\section{CĂTĂLINA Mititelu}

\section{Service de l'Église orthodoxe roumaine en faveur des migrants}

\section{Résumé}

Au fil des pages de cette étude, le lecteur aura l'occasion d'apprendre que les migrants qui se sont installés en Roumanie après 1998 ont fait l'objet d'une attention particulière de la part de l'Église orthodoxe roumaine; en même temps, leur présence parmi les Roumains a permis à l'Église de souligner qu'elle était et est toujours une «servante»de l'homme, y compris les réfugiés, les migrants, les apatrides. En effet, l’Église orthodoxe roumaine, par ses ecclésiastiques, croyants et moines, déploie des efforts considérables pour surveiller et résoudre la crise migratoire. Grâce à cette approche, initiée et améliorée par l'actuel Primat, Sa Sainteté le Patriarche Daniel, tant dans le pays que dans la diaspora, le problème de la migration a pu non seulement être suivi, mais aussi résolu conformément aux règlements de l'Église, conformément au droit de l'État et conformément à celui de l'Union européenne, c'est-à-dire les États membres de l'UE où notre Église a une partie de sa diaspora. Le lecteur pourra noter que dans ses activités de monitorage et de résolution du problème des migrations, notre Église a pris en compte à la fois les orientations émises par les organes du Conseil œcuménique des Églises et les principes 
directeurs formulés par les dirigeants des deux Églises : catholiques et orthodoxes, c'està-dire Sa Sainteté le Pape François et Sa Sainteté le Patriarche œcuménique Bartholomée $\mathrm{I}^{\mathrm{er}}$ de Constantinople. Nous parlons de leurs Déclarations conjointes sur la migration, qui témoignent de la nature œcuménique de leur approche de la question examinée.

Mots clés : crise migratoire, phénomène migratoire, hospitalité, diaspora 